\title{
Geomorphology of the Coastal Plain of the Asir Region, Using Remote Sensing and GIS Techniques, Saudi Arabia
}

\author{
Mena Mohamed Essam Hassan Elassal*
}

\begin{abstract}
Coastal Plain in Asir Region under investigation stretches in the southwest of Saudi Arabia. The geo-morphologic features, shoreline configuration, sediment characteristics and dynamics have been established for understanding the processes that influence the coastal environments. The shoreline of the studied area is not linear and smooth; instead, it is complicated by arcuate beaches, sharms, inlets, lagoons, barriers and rocky hills. The width of the coastal plain varies widely; it is wide and featureless towards the south of the study area while being narrow and bounded by resistant sea cliffs towards the north of the study area. Asir coastal landforms include a marsh system, inlet and swamps, wave swash, dunes, shoreline processes, beach bars, a spit system, wadi systems and sabkha systems. Conditions on such beaches change rapidly. It is a unique environment, being characterized by some of the major geological environments (e.g. coastal reefs, mangrove stands, marshes, sabkhas, alluvial fans, sea cliffs, recent sediments, sand dunes, sabkhas, sand beaches, lagoons, nebkas, wadis, coral reefs, organic matter, and vegetation areas). The aim of this paper is to follow and assess the environment and characteristics of landforms. The previous procedures happen through measuring biodiversity, landforms and geomorphological processes on the coastline. The study uses several methods such as field study, collection of samples from different geo-morphic environments of the coastal area, comparing the geo-morphological and environmental changes from maps and also using remote sensing and GIS techniques. [Bul. Soc. Géog. d'Égypte, 2020, 93: 25-53]
\end{abstract}

Key Words: Asir Region, Coastal Plain, Geo-morphology Features, GIS, RS.

\section{Introduction}

In general, little attention has been paid to the geo-morphology of the coastal stretch in the eastern Red Sea coastal plain. The coastal plain towards the southern Red Sea coast has more than $40 \mathrm{~km}$ wide shelf, and extremely vast coastal plain. It is even wider further south to Yemen. Information on the north of Ash-Shuqayq to Al-Haridhah is limited. It is available from the published papers dealing with the geo-morphologic features and sedimentologic aspects of the coastal area of the Red Sea (Jado \& Zotl, 1984; Tag, 1986; Tag, et al., 1990; Abou Ouf \& El-Shater, 1992; Gheith \& Abou Ouf, 1996; Basyoni, 1997 and Gheith, 1999). The coastal plain is interrupted, where the basement occurs, and represented by a large area of plateau basalt

* Assistant Professor of Physical Geography, Department of Geography, Faculty of Humanities, King Khalid University, Saudi Arabia.

For Correspondence: e-mail: menaelassal_83@yahoo.com 
and Pleistocene alluvial terraces. Red Sea relief is related to the tectonic movement resulting from the opening of the Red Sea. The climate is arid, and the erosional processes play a dominant role in the development of the present landscape (Coleman, 1993). The marginal shelf of the Red Sea is composed of coral banks and reef limestones that are covered by a veneer of carbonate sand. The morphology of the Red Sea shelf in the western coast of Saudi Arabia has been controlled mainly by the effect of coral growth.

Nbhan (2004) studied the geo-morphology and sedimentology of Ash Shuqayq and suggested several landform characteristics for shore, aeolian and wadi processes. Wadi runoff carries much terrigenous material and organic matter. Corals and lagoons are particularly sensitive to these excessive inputs. Gheith (2000a) focused on sedimentary deposits on the eastern coast and the impact of coastal activity. Gheith (2000b) suggested that sediment characteristics and behaviour in the near-shore zone vary in different sub-environments. In land from the coast, the plain rises into an eastern plain consisting largely of a pediment with alluvium and outwash sands and gravels on tertiary or crystalline rocks, and hence to the basement hills. In the south, there is no relief to the flat coastal plain other than the Jizan salt dome which rises $50 \mathrm{~m}$ above sea level and the volcanic lava flow between the north of Ash-Shuqayq and Al-Huraydah.

So, the study of local geology helps the authors to understand how coastal geo-morphology, lithology and tectonics influence the distribution and transport of littoral sediment in the near shore along low topography shoreline. It is found that the main forms were composed of a marsh system, inlet, swamps, wave wash, dunes, shoreline processes, beach bars, a spit system, wadi systems, and sabkha systems (Al-Washmi, et al., 2005, p.58).

\section{Study Area}

Coastal Plain in Asir Region is located between the latitudes $17^{\circ} 44^{\prime} 23^{\prime \prime}$, $18^{\circ} 39^{\prime} 35^{\prime \prime} \mathrm{N}$, and longitudes $41^{\circ} 17^{\prime} 56^{\prime \prime}, 41^{\circ} 57^{\prime} 37^{\prime \prime}$. It is about $40 \mathrm{~km}$ wide with a length of about $140 \mathrm{~km}$. It contains complex sand dunes, swamps, tidal flat and sabkhas on the north eastern side. The shoreline north and south of Asir region coast is not linear and smooth. Instead, comprises arcuate beaches, sharms, inlets, rocky hills, barrier, spits and lagoons. Moreover, Asir region coastal plain is also cut across by many wadis, lagoons, outlets, tidal inlets and tidal channels which act as protected areas, where mainly coarse-grained material is deposited. North of Ash-Shuqayq near Al-Hurayda region lie Sharm At-Tanah and Jabal AlRaqabah. However, south of Ash-Shuqayq lie Ras Suwad and Ras Masud (Figure 1). 


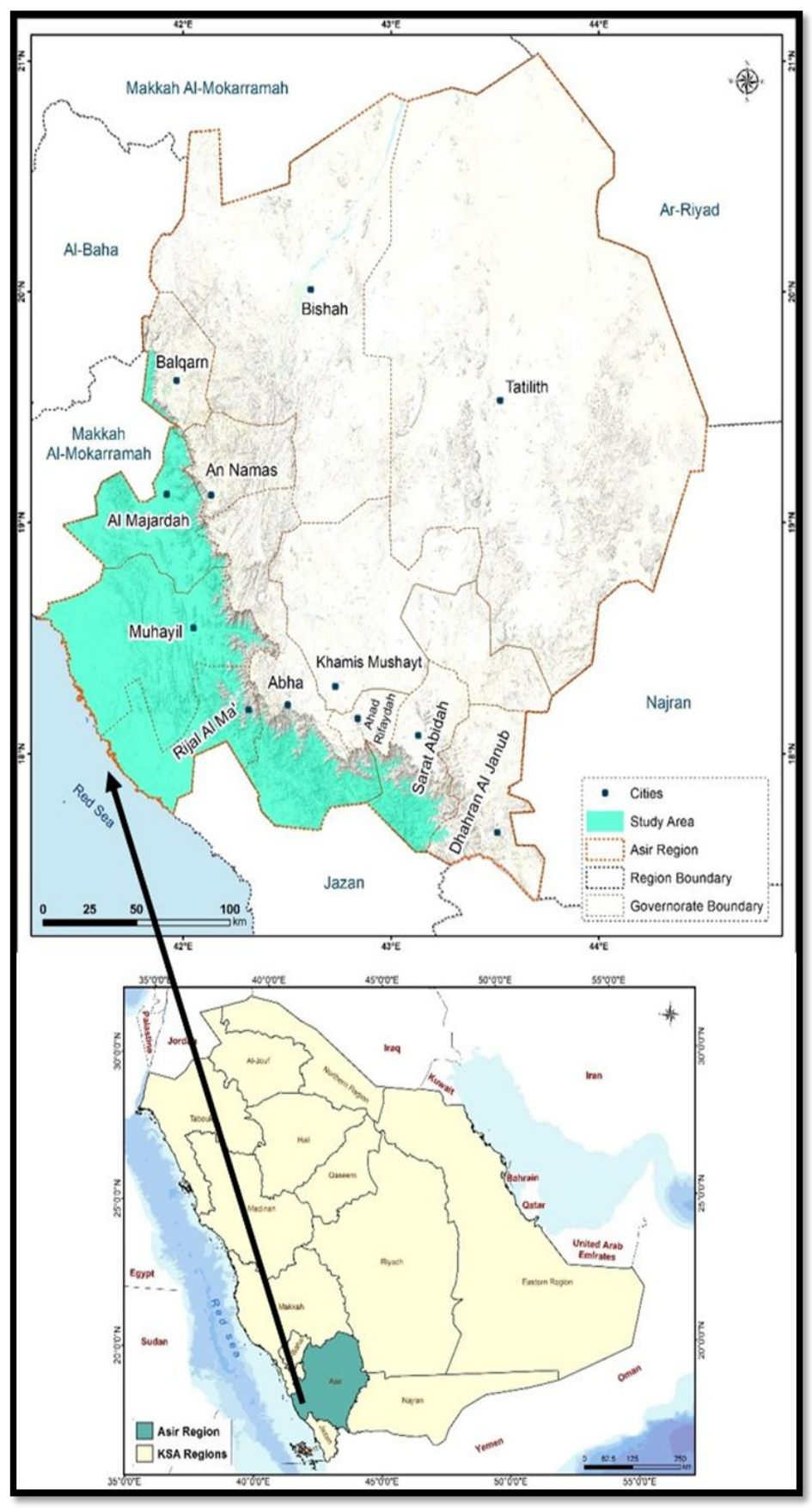

Source: KSA Administrative data, updated guidebook of the population names manual in the preparatory stages for the agricultural census $1436 \mathrm{AH}$.

Figure 1. Location map of the study area. 
The climate of the study area is of a hot arid desert type. Within the orbital range, the climate is hot and humid in summer and moderate in winter, with rainfalls in summer and autumn seasons. Based on the records by the General Authority of Meteorology and Environment Protection (2017) which cover the period between 1976 and 2017, the temperature reaches a maximum of $33.5{ }^{\circ} \mathrm{C}$ within the period between March and August, and a minimum of $26.6{ }^{\circ} \mathrm{C}$ in the period between January and February. The relative humidity ranges between a maximum of $100 \%$ in the period between August and November, and a minimum of 5\% in the period between January and March. The precipitation rate is about $55 \mathrm{~mm} /$ year.

Coastal Plain in Asir Region can be described as a broad, low relief depositional coastal plain. Conversely, Al-Haridhah coast (north of AshShuqayq) is an emergent shoreline with rocky headlands giving rise to pocket beaches that disrupt the wave-induced long-shore sand transport or the littoral drift in the surf zone.

The low-lying Ash-Shuqayq coast sediment cover is generally thick, and the distribution of the littoral sediments on the shoreface provides important information regarding not only the sources of the sediments but also the modes and pathways of transport. However, some parts of the beach consist of a low-lying hard coral reef platform and have a very thin to nonexistent sediment cover.

\section{Objectives:}

The objective of the paper is to describe the geomorphic coastal features and to delineate sediment transportation and its distribution along Asir Region coastal area. In addition to different sub environments to assess sediment processes and transport. Following field and laboratory analyses, results are examined to explain differences in sediment chemical composition, characteristics and shoreline distribution Consequently, field and laboratory analyses identify differences in Asir Region sediment chemical composition, characteristics and shoreline.

\section{Sample Collection and Methods of Study:}

The study uses several methods. First, it utilizes a field study of 5 days in January 2020 , from $5^{\text {th }}$ to $10^{\text {th }}$ January. It employs collected samples from different geomorphic environments in the coastal area. Besides, it compares the geomorphological and environmental changes from maps and uses remote sensing and GIS techniques, which are used as described below:

1. A reconnaissance survey of the Coastal Plain in Asir region was carried out to collect and describe different geomorphic environments that 
characterize the coastal zone. These include nearshore, shoreline, beach, beach bars, sand dunes, tidal inlets and flats, sabkhas, lagoons and wadis. Out of these, environment samples are collected and landforms are classified, described and photographed. The influence of geology and coastal morphology on sediment distribution and transport is interpreted. Sediment samples from various geo-morphic environments between Al-Huraydah (north of Ash-Shuqayq) and Itwad (south of AshShuqayq) are collected. A summary of this collection is given in Table (1) and Figure (2). The samples collected were texturally analyzed and classified. Moreover, a sand fraction is mechanically analyzed by the sieving technique adopted by Folk (1962). Graphic grain size parameters are also computed following Folk \& Ward (1957).

Table 1. Samples collected from different geo-morphic environments of Coastal Plain in Asir region.

\begin{tabular}{|l|l|l|l|l|l|}
\hline Samples & $\begin{array}{l}\text { Station } \\
\text { numbers }\end{array}$ & \multicolumn{1}{|c|}{ Lat } & Long & Altitude & $\begin{array}{c}\text { Sub- } \\
\text { environments }\end{array}$ \\
\hline 1 & SH 1 & $17^{\circ} 41^{\prime} 30.66^{\prime}$ & $42^{\circ} 01^{\prime} 17.72^{\prime \prime}$ & $3 \mathrm{M}$ & Foreshore \\
\hline 2 & SH 2 & $17^{\circ} 43^{\prime} 03^{\prime \prime}$ & $41^{\circ} 59^{\prime} 28.58^{\prime}$ & $1 \mathrm{M}$ & Foreshore \\
\hline 3 & SH 3 & $17^{\circ} 43^{\prime} 16^{\prime}$ & $41^{\circ} 58^{\prime} 13.75^{\prime}$ & $1 \mathrm{M}$ & Foreshore \\
\hline 4 & SH 4 & $17^{\circ} 46^{\prime} 15.93^{\prime \prime}$ & $41^{\circ} 54^{\prime} 30.46^{\prime}$ & $1 \mathrm{M}$ & Foreshore \\
\hline 5 & SH 5 & $17^{\circ} 50^{\prime} 15.70^{\prime \prime}$ & $41^{\circ} 48^{\prime} 6.15^{\prime}$ & $2 \mathrm{M}$ & Foreshore \\
\hline 6 & SH 6 & $17^{\circ} 51^{\prime} 52.79^{\prime}$ & $41^{\circ} 46^{\prime} 27.17^{\prime}$ & $2 \mathrm{M}$ & Foreshore \\
\hline 7 & SH 7 & $17^{\circ} 53^{\prime} 31.21^{\prime \prime}$ & $41^{\circ} 44^{\prime} 55.85^{\prime}$ & $1 \mathrm{M}$ & Foreshore \\
\hline 8 & SH 8 & $17^{\circ} 55^{\prime} 23^{\prime \prime}$ & $41^{\circ} 42^{\prime} 35.81^{\prime \prime}$ & $2 \mathrm{M}$ & Foreshore \\
\hline
\end{tabular}

2. Satellite images, with high spatial and spectral resolution, were acquired, processed and interpreted to produce baseline maps for the physical environment of the study area. For this purpose, ETM presented this information in the form of maps to interpret the different images. Two Landsat images cover the study area (path 167/row 48 and path 168/row 47). In this study, the following was used: Landsat MultiSpectral Landsat Thematic Mapper (TM); Landsat Enhanced Thematic Mapper Plus (ETM+); Advanced Spaceborne Thermal Emission and Reflection Radiometer (ASTER). Each satellite image was orthorectified using a digital elevation model (DEM) image of the study area and then rectified to the UTM Zone 38 and WGS84 to facilitate their comparisons. Several digital enhancement techniques were employed to map and differentiate the different lithological, geomorphological and structural features, as well as the change of coastline. 


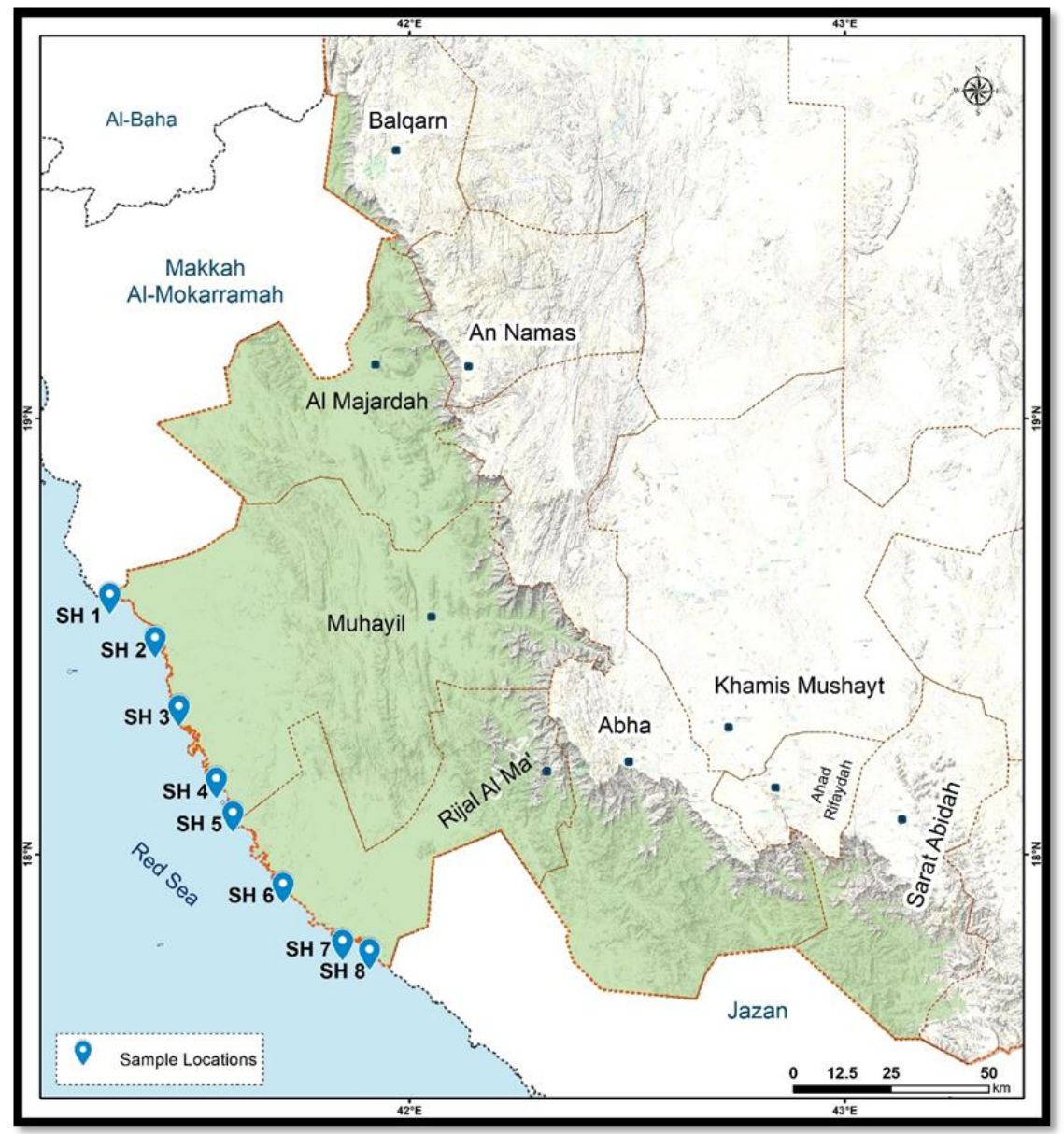

Source: Suttle Radar Topography Mission (SRTM) 3 Arc-Second Global, NASA and NGA (2011), and the field study in January.

Figure 2. Location map of Coastal Plain in Asir Region and the samples collected.

\section{Geology and Structure:}

Coastal Plain in Asir Region constitutes a part of the western Arabian Shield, which is covered by Neoproterozoic rocks consisting of various types of volcanics and volcaniclastics, together with several varieties of intrusives (diorites, granodiorites and granites). These rocks are covered by Tertiary and Quaternary lavas and sediments and in some places by recent sediments and sabkhas. Three distinct geologic units could be distinguished in the concerned area. These are from the oldest to youngest: the Neoproterozoic basement, the tertiary sediments and lavas, and the Holocene sediments and sabkhas. The Neoproterozoic rocks lie in the eastern part of the area, i.e. the area that is occupied by the Red Sea hills and pediments. They consist of 
volcanic rocks, comprising andesite and dacite that are intruded by plutonic rocks including diorite and granite (Plate 1). Shumaysi, Usfan and Hadat Ash-Sham Formations that are covered by basaltic lavas represent the Tertiary rocks. The Holocene unit includes the recently emerged marine deposits and corals, the recent basaltic lava flows, the wadi alluvium, sabkha deposits and the aeolian sands along the coastal plain and pediments.

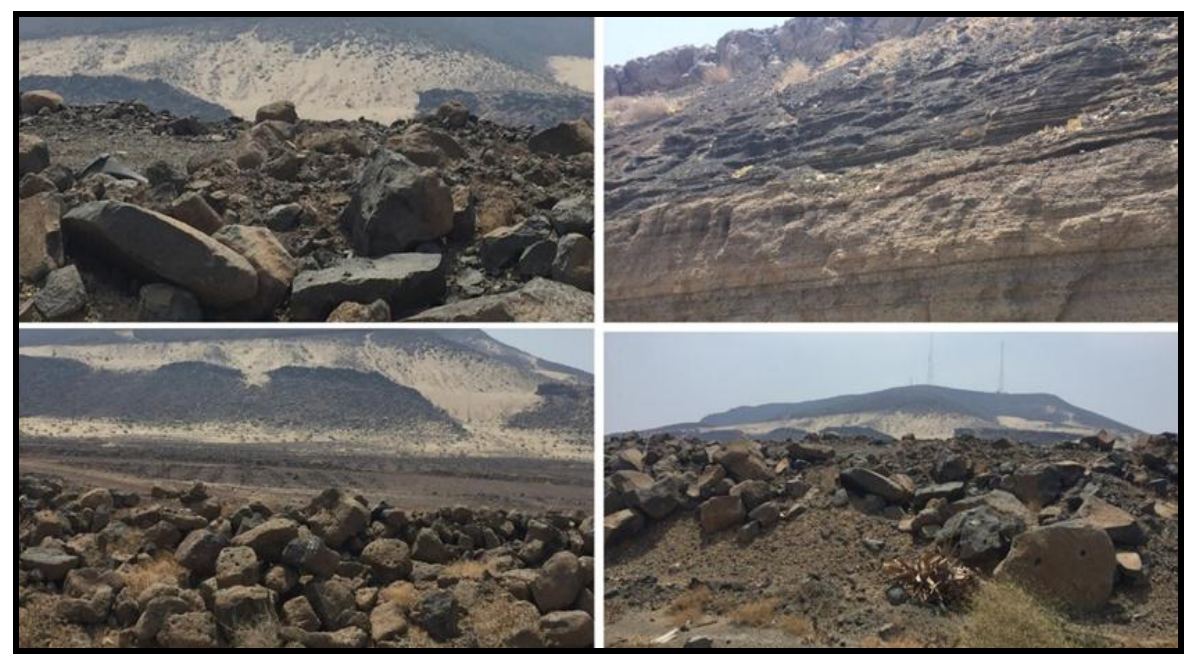

Plate 1. Photos showing volcanic rocks, comprising andesite and dacite, intruded by plutonic rocks, including diorite and granite, field Study in the Area on 5/1/2020.

To identify the region of Asir coast, the region was divided into the following sectors:

- Al-Haridhah Al-Qahma Sector: This sector is dominated by the sediments of fourth time, related sediments, and the volcanic rocks of the third and fourth times. Its slope ranges between 0-20 degrees, and there are granite rocks in the direction of the east.

- Al-Qahma Al-Birk Sector: It is dominated by the volcanic rocks of the third and fourth whose slope ranges between 0-20 degrees. In addition, there are times granitic rocks in the direction of the east. There are also dikes and faults.

- Al-Birk Amaq Sector: This sector is dominated by the volcanic rocks of the third and fourth times, and their slope ranges between 0-20 degrees in addition to the presence of sedimentary volcanic rocks at the east of each of Al- Qahma, Dhahban, and Al- Birk.

- Amaq-Saeedat Alswaleha Sector: This sector is dominated by the fourth time deposits and the sediments related to them, as well as the volcanic rocks of the third and fourth times. Their slope ranges between 0-20 degrees. 
The distribution of the geo-morphologic units across the area, as well as the previously mentioned lithologic units, is strongly controlled by the structures. As the area constitutes a portion of the Red Sea coast, it is implicit that it shared the history with the Red Sea rift that evolved during the Tertiary time through a series of tectonic events that resulted in the Red Sea rift. Therefore, the tectonic events that brought about the Red Sea rift had their impact on the evolution and development of the litho-stratigraphy and geo-morphology of the study area (Coleman, 1984).

The borders of the geo-morphologic zones are aligned in concordance with the Red Sea shore and are generally aligned in NNW direction. This alignment is as well concordant with that of the faults which formed the Red Sea Rift as a spreading ocean (Schmidt, et al., 1982). In addition, Sharm Ubhur is interpreted by the same authors (e.g. Schmidt, et al., 1982; Coleman, 1984) to be an inland extension of the transform faults that compensate for the differential movement between the different parts of the spreading ocean crust beneath the Red Sea, geology and structure map is shown in Figure (3).

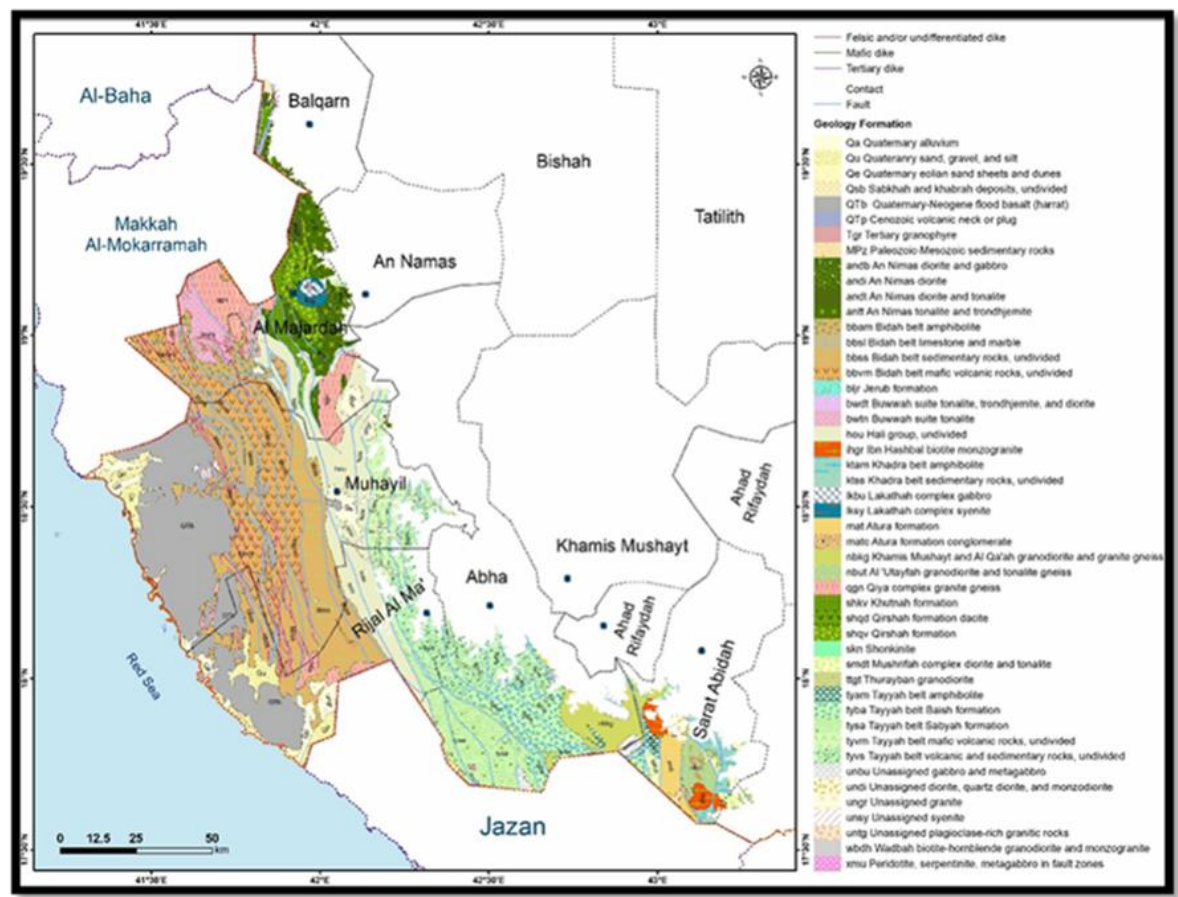

Source: Arabian shield geology project, SGS, 2006, 500k.

Figure 3. Geological map of the study area. 


\section{Geomorphology:}

The geomorphology of the coastal Asir region has complex landforms. These include sand dune processes, marsh and inlet systems, sabkha systems, carbonate systems, wadi systems, sea cliffs and wave swash processes. Conditions on such beaches change rapidly. Besides, coastal marshes and inlets as well as sand dunes are common components of AshShuqayq coast. The location of the studied landforms which characterize the studied coastal area is represented. The coastal plain forms a 30 to $60 \mathrm{~km}$ wide coastal strip with a northwest to southeast and north, northwest to south, southeast trend. The shoreline follows structural lineations, the alignment of the escarpment and the orientation of the Red Sea shelf and trough appear in V-shaped channels (wadis) traversing the Tihama Plain principally to the west and southwest. The flood plains of this modern drainage system are covered by silt, sand, and subordinate gravel. Toward the coast, the sedimentary load of most wadis is distributed as fans over sabkha and tidal mudflats, and many channels do not reach the shoreline. None is active enough to generate deltas along the coast. Many volcanic and salt intrusions and flows are found in the coastal plain, as well as volcanic rocks and Sabkha or saline tidal mudflats.

Three major geo-morphologic zones are clearly distinguished in a geomorphologic map shown in Figure (4). These zones are aligned in subparallel orientation in an N-S direction. They are, from west to east, as follows: (1) The Red Sea and its shoreline features, (2) The coastal plain, and (3) The coastal hills and pediments.

\section{Results and Discussions}

Results of our research are investigated and provided under the appropriate sub-heading.

\section{Shoreline Evolution:}

The coastal plain of Asir region can be geo-morphologically divided into shore, lagoon, aeolian and wadi landforms (Al-Washmi, et al., 2005). The Asir region is characterized by its many curves and meanders in many parts of it. These include backshore plain, tidal inlets, shoreline, sand dunes, lagoons, shrooms, marshes, wadis, marine heads, tidal flats and sabkhas. The recent minerals and sediments represent the previous different geo-morphic environments that constitute the coastal plain of Asir region (Gheith, et al., 2006). In general, the study region is a broad lowrelief depositional coastal plain. Along the low-lying coast, the sediment cover is generally thick. The morphology of the shoreline includes coastal mountains and sea cliffs especially to the north, while in the middle and 
south, lagoons, wadi mouths, sand dunes and tidal inlets are common. Aeolian activity, together with the wadis, contributes most of the terrigenous material to the shore zone.

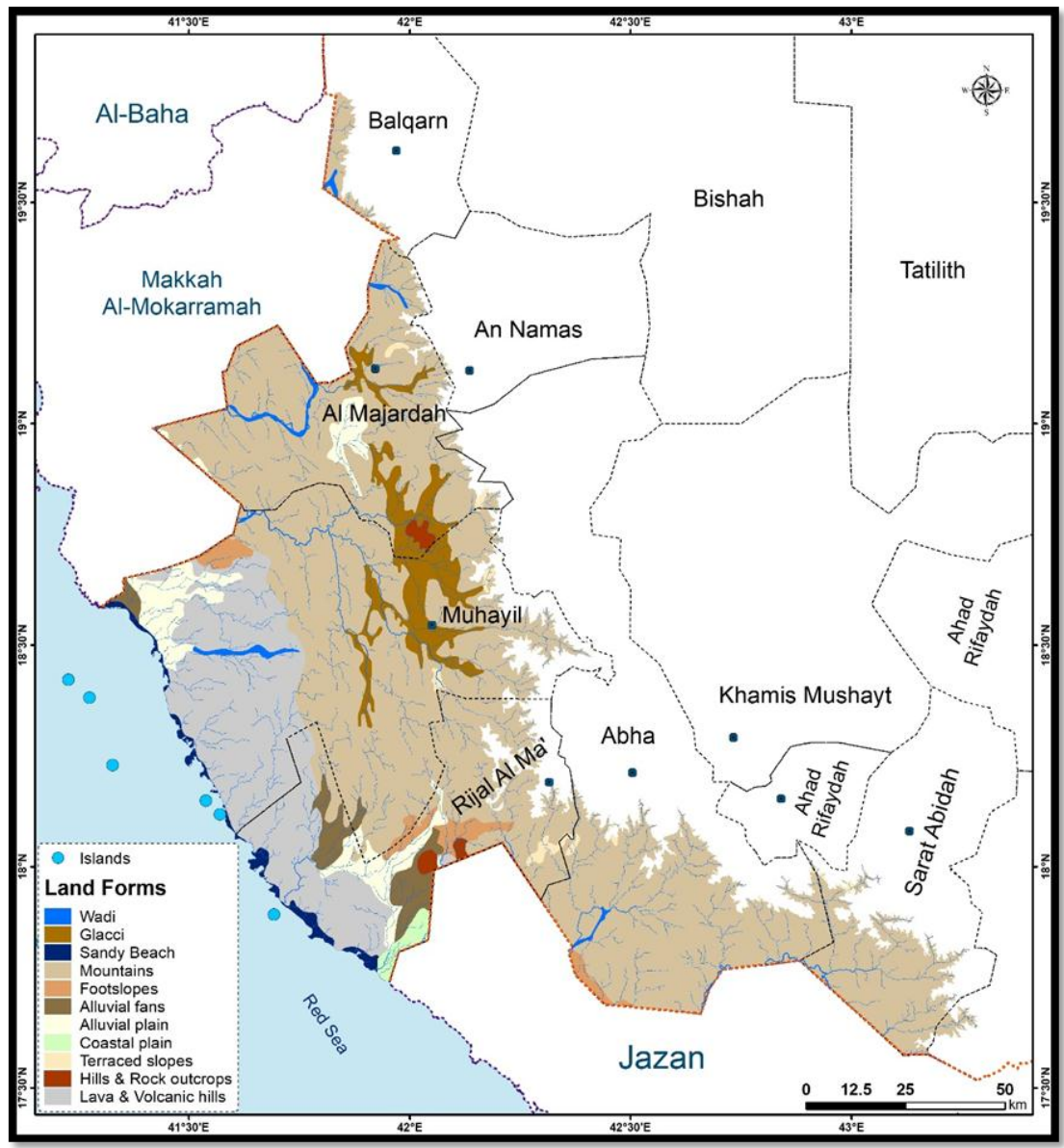

Source: Field study, Geologic Map 500k, Topographic Maps 250k, SRTM Runoff Characteristics, and Land resources Map (Land Resources Atlas, MEWA, 250k, 2011G).

Figure 4. Constructed schematic map showing the different geo-morphic environments along the Coastal Plain in Asir Region.

This study recorded high erosion rates in the northern and western parts of the investigated area. However, the retreat of the shoreline was at differentiated rates, between 2000 and 2020; $50 \%$ of the coastline eroded and $50 \%$ accreted. The greatest area of erosion was $6.65 \mathrm{Km}^{2}$, and the greatest accretion was $14.96 \mathrm{Km}^{2}$. The average erosion rate was $0.33 \mathrm{~m} / \mathrm{y}$ between 2000 and 2020, and the average precipitation rate was $0.75 \mathrm{~m} / \mathrm{y}$ between 2000 
and 2020. The length of the coastline in the year 2000 was $419.13 \mathrm{~km}$ and the length of the coastline in the year 2020 was $440.235 \mathrm{~km}$. However, several factors are responsible for the coastal change. This can be explained by the exposure of shoreline to direct waves. Moreover, the speed of weathering and erosion processes was observed in the rocks which were considered the basic component of the head rocks. Furthermore, low rates of erosion can be observed in the southern part of the study area with the occurrence of deposition processes in other areas. This can be explained as this area was exposed to the work of the coastal currents which transport and/or deposit some sediments at this region. Figure (5) shows comparative results of two satellite images of the change of coastline of the study area from 2002 to 2020, and Figure (6) shows the division of the study area changes into 6 sectors, From the north of the study area to its south, as follows A, B, C, D, E, and F.

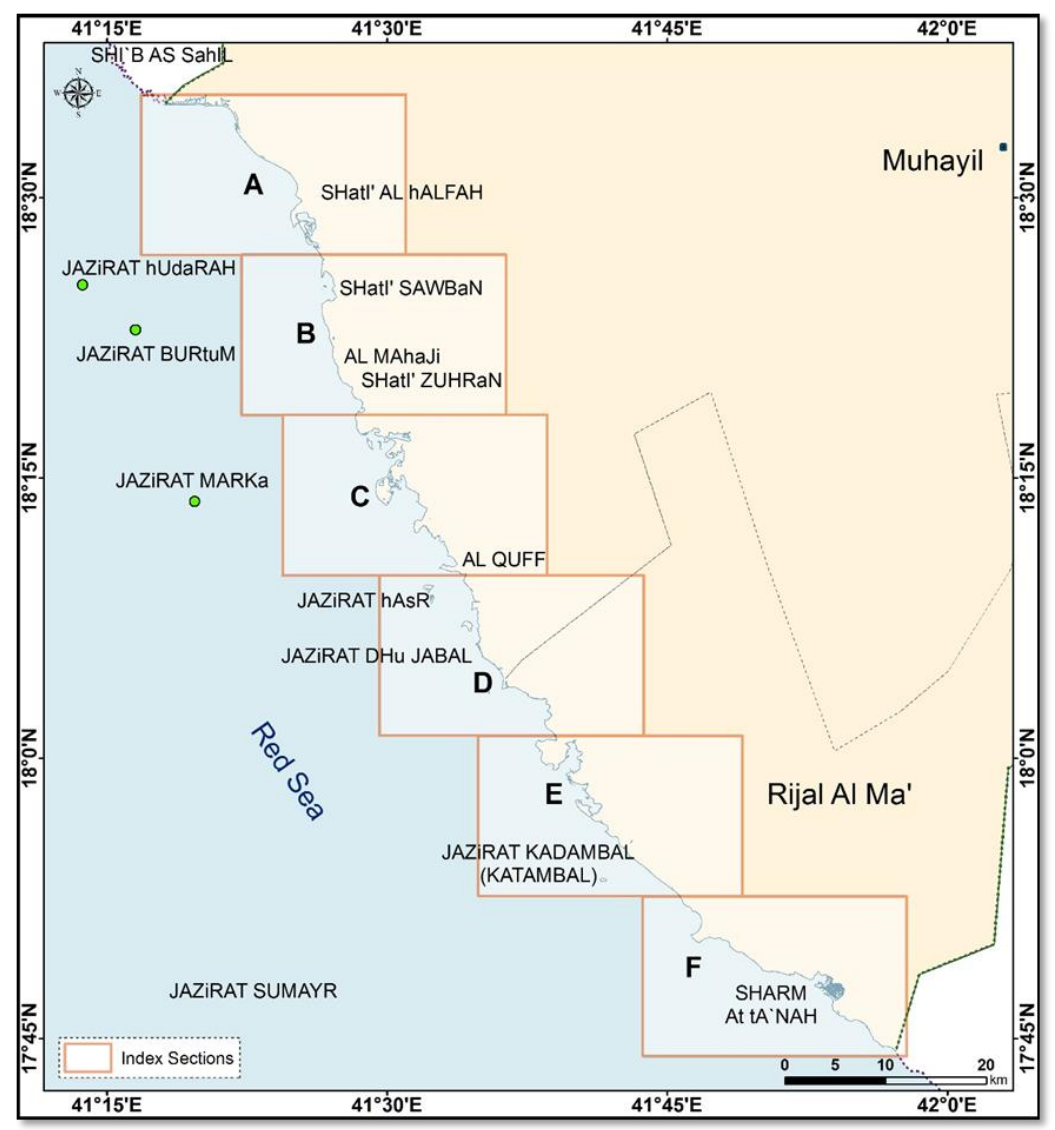

Figure 5. Comparative results of two satellite images of the change of coastline of the study area from 2002 to 2020. 


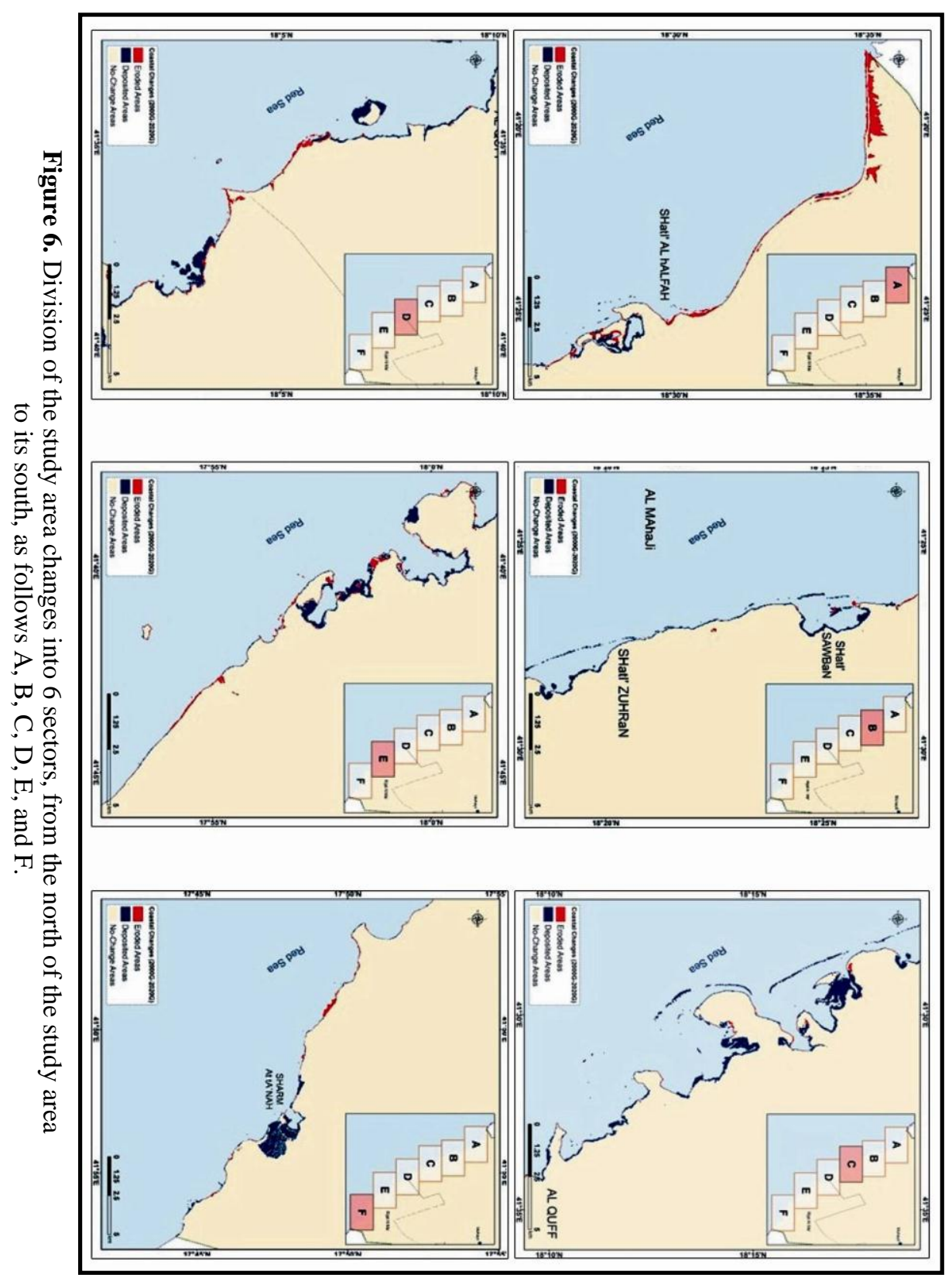




\section{Geomorphological Features:}

The coast of the Asir region is characterized by its numerous curves and meanders in several parts. It is formed in the form of sharms, khours, lagoons, coastal lakes, and marine heads. These phenomena are more widespread in the southern sector of the coast of the study area than in the northern sector. The coast of the study area is divided according to the following phenomena:

- The southern sector of the coast of the study area: it is located between Al-Haridhah and Al-Birk. There are lagoons, lakes, cliffs and shorelines on the beaches in front of the mountains and volcanic Aharat.

- The northern sector of the coast of the study area: It is located between Al-Birk and Saeedat Alswaleha. There are khours and sharms. The marine heads and spits are spread in the Dhahban, Al-Qahma and Al-Birk, and it almost disappears in the rest of the sides of the study area. The coast of the study area is also distinguished by its richness in coral reefs, between Al-Haridhah and Al-Birk.

\subsection{The Beach:}

Beaches are the result of the accumulation of sediment deposited by waves and currents in the shore zone and extend from the upper most limit of wave action to the low-tide mark. They are typically composed of sand and/or pebbles. In general, sandy beaches are formed from the partly eroded material from adjacent parts of the coast, partly by fluvial sediment and partly by the sand carried shoreward from the sea floor (Bird, 1984). The topographic configuration of Asir beach includes the following units: backshore, foreshore and sand dunes. To the north of Asir region, pocket beaches are noticed. To the south of Asir region, the beach is much wider and longer and is distinguished by lower gradient shore-face and low-lying marine reef platform. Sediments on the beach are coarser than the intertidal sediments because fine sediments are dispersed seaward due to wave action in that area. There is a wide range of sediment texture exhibited by Asir beach, which reflects varying energy conditions in the study area. Furthermore, variability in the sources of the sediments and the reworking processes operative in the littoral zone are also observed in grain size. The coarse-gravelly sand bed material results as runoff down the wadis during flash floods (Al-Sayari and Zotl, 1978).

These flash floods are highly localized and of variable intensity. The terrigenous sediments from the wadis are mixed with in situ available skeletal carbonate material in varying proportions in the beach and littoral zone. Such mixing and subsequent reworking by the near-shore processes gives rise to the variation in texture. Generally, along the whole beach zone, 
foredune ridge sand is arranged in the form of complex sand dunes parallel to the shore and constitutes the youngest recent material in the study area.

\subsection{Beach Ridge:}

A beach ridge is a continuous linear mound of coarser sediment near a high water line (Reineck \& Singh, 1975). In front of a beach ridge, a sandy beach is always present. Asir region beach ridges are made up of sand and gravel. They developed mainly during rainy storms and deposited at the mouths of the wadis, and then re-deposited by wave processes. It is mainly horizontally laminated sand and gravel layers (Plate 2).

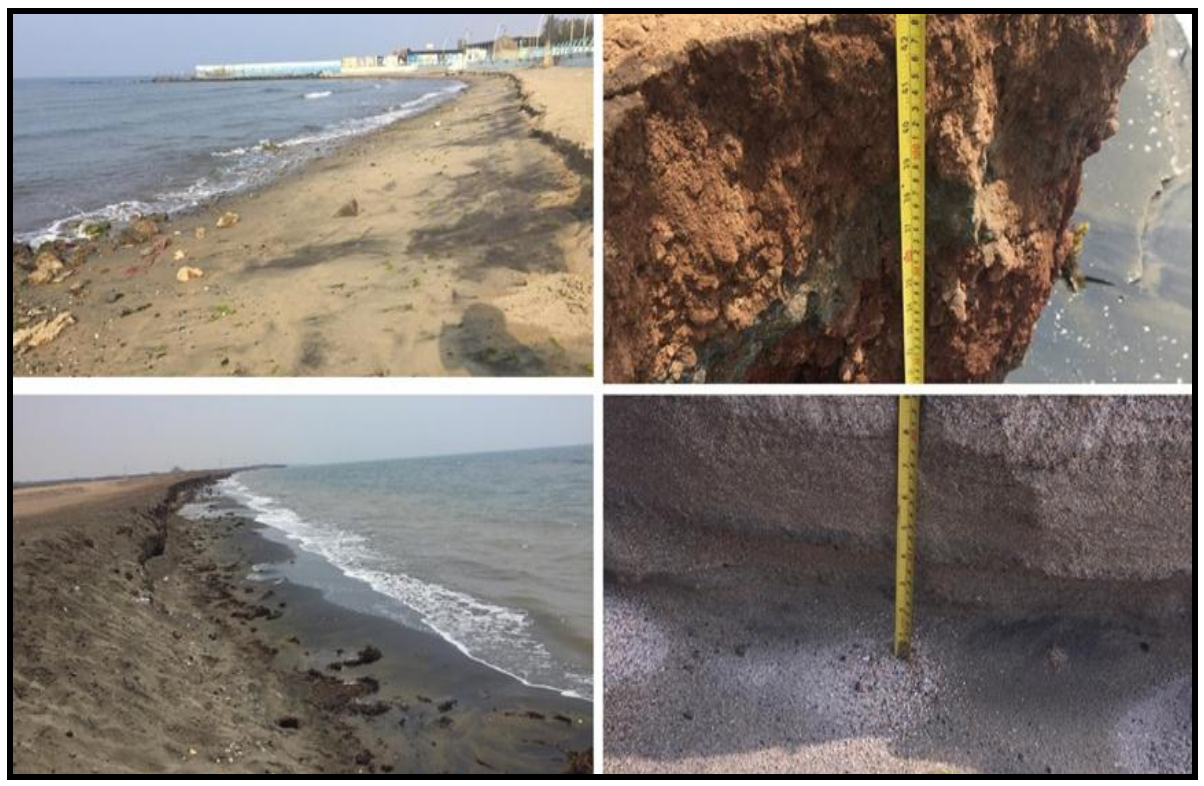

Plate 2. Photos showing beach ridges of sand and gravel, field Study in the Area on 6/1/2020.

\subsection{Sandy beach:}

Asir region coastal plain extends from the upper most limit of wave action to the low-tide mark. It is typically composed of sand or pebbles. In general, sand beaches are supplied partly by material eroded from adjacent parts of the coast, partly by fluvial sediment and partly by sand carried shoreward from the sea floor (Bird, 1984, p. 320). The geo-morphic units of the coastal plain of Asir region coastal plain include backshore, foreshore and sand dunes (Plate 3). Generally, beach sediments are backed by aeolian sand that is arranged in the form of complex sand dunes or in the form of longitudinal bar or ridge parallel to the shore and constitute the youngest recent material in the study area (Nbhan, 2004). 


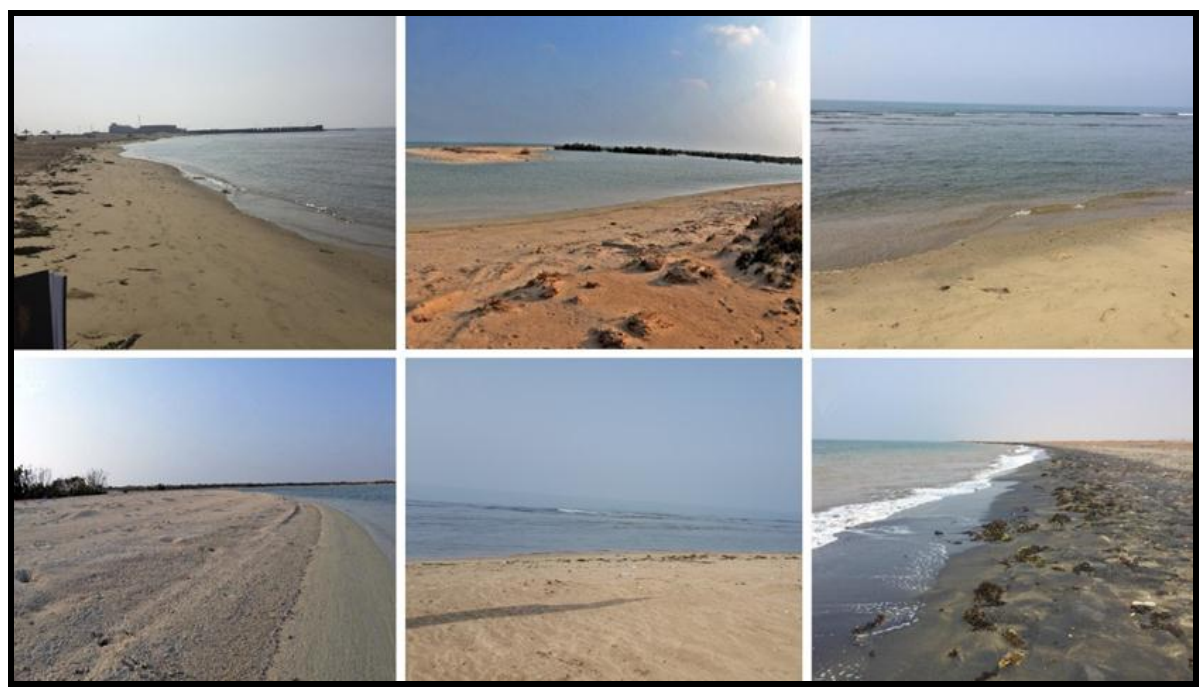

Plate 3. Photos showing sandy beach, including backshore and foreshore, field Study in the Area on 6/1/2020.

\subsection{Black Sand Beach:}

Black sand is a heavy, glossy and partly magnetic mixture of usually fine sand that is found as part of a placer deposit. The mechanical concentration of resistant heavy minerals takes place in the beach environment, mostly under high energy conditions and their petrological composition is mostly controlled by the original source rocks (Basu and Molinaroli, 1989). They spread on the coast of the study area in many places (Plate 4). Such sand contains about $3 \%$ of some important economic minerals; namely, magnetite, ilmenite, zircon, rutile and monazite. Black sand is composed of volcanic minerals, and lava fragments are usually composed of minerals that are relatively resistant to weathering. Such minerals are tourmaline, magnetite, garnet, rutile, ilmenite, and zircon. Marine processes leave heavy metals on the shore, although such metals fall under the category of fine and very fine sand, marine processes cannot carry them, and thus remain on the front beach. Black sand is considered as valuable wealth in Saudi Arabia, and so many industries can be developed in Saudi Arabia based on this wealth.

\subsection{Sand Dunes and Sand Flats:}

Asir region coastal plain is distinguished by extensive and various coastal sand dunes. In general, the occurrence of dunes on the coast is directly related to sand supply and a favorable wind regime (Davis, 1985). Foredunes consist of sand that first begins to accumulate. This occurs where wind speed is reduced by an increase in surface roughness or by primary 
airflow instabilities. The same basic aeolian processes responsible for the formation of desert dunes affect coastal dunes, but additional factors must also be considered. The key variable determining whether dunes will develop is the rate of abstraction of sand from the beach.

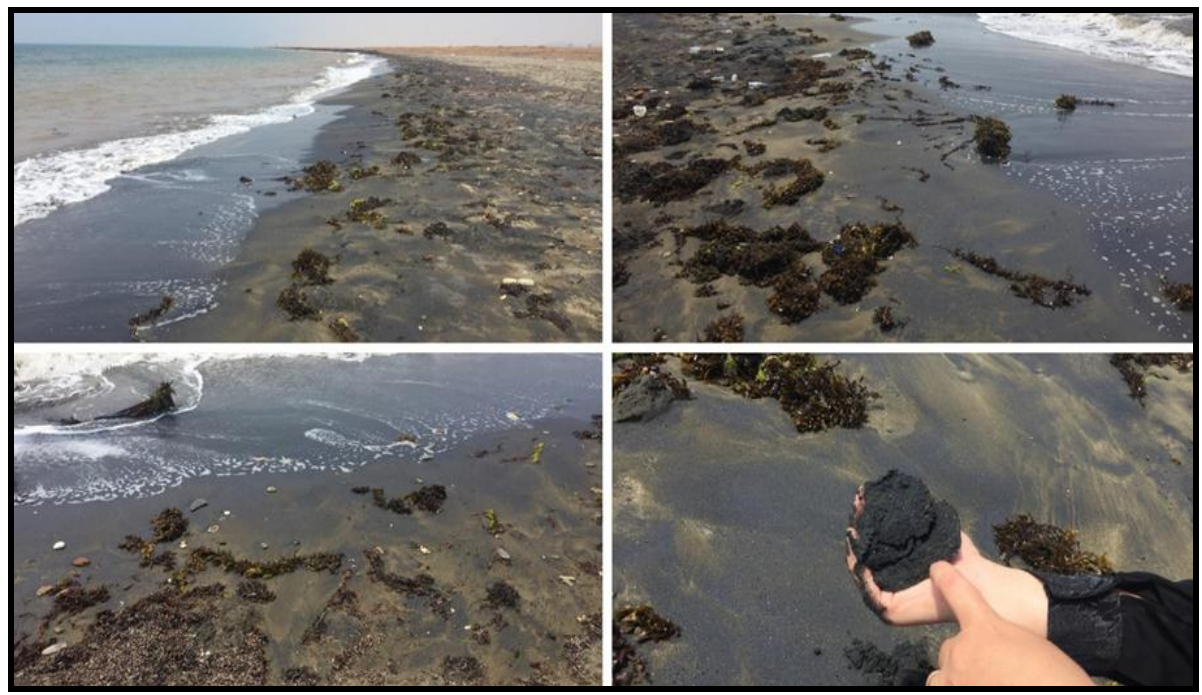

Plate 4. Photos showing black sand beach, field Study in the Area on 6/1/2020.

Other important variables are vegetation effects and the nature of the backshore zone (Summerfield, 1991). Sand dunes show evidence of movement with high topographic relief and include Seif and Barchan dunes. In general, it was observed that along most of the coastline, active dune systems are common, forming sand dune ridges where the foredune marks a boundary between hydrodynamics and aeolian environments (Plate 5). Nbhan (2004) emphasized initiation and dune evolution and their interaction with the processes including vegetation influences.
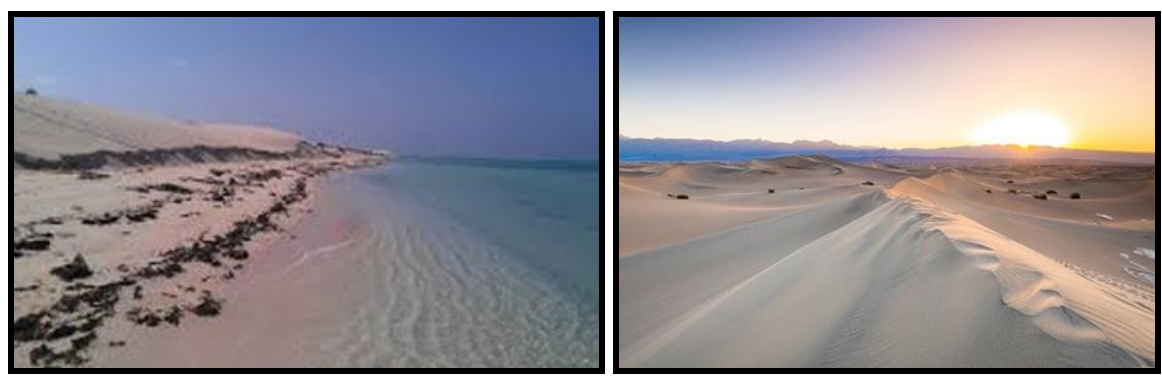

Plate 5. Photos showing sand dunes and sand flats, field Study in the Area on 6/1/2020. 


\subsection{Rocky Cliff and Pocket Beaches:}

This type of beach is common in north Ash-Shuqayq, at AlHuraydah. It consists of nearly $60 \mathrm{~m}$ high hills of basaltic rocks on the shoreline (Plate 6). In between, pocket beaches are also noticed. These rocky hills indicate volcanic eruption that built up a thick succession of lava associated with the tectonics of the Red Sea region.

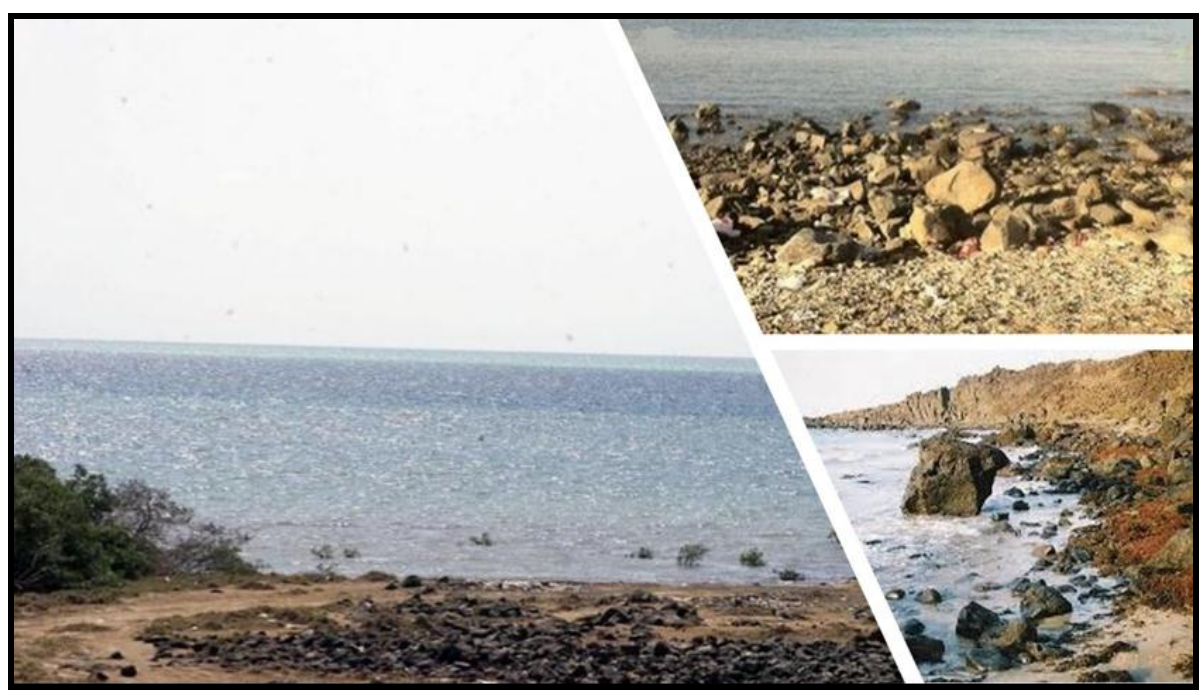

Plate 6. Photos showing rocky cliff and pocket beaches north Al-Haridhah coast, field Study in the Area on 6/1/2020.

\subsection{Salt Marshes and Sabkhas:}

Asir region coastal plain is characterized by many vegetated mud flats, sabkha deposits and salt beds. The coastal sabkhas are characterized by the presence of evaporite minerals which have accumulated on the top to form a hard crust followed by a soft or loose soil zone. In general, the sabkha surface is very flat with no physical obstacles. These sabkhas extend for approximately more than $1 \mathrm{~km}$ from the waterline. In principle, Asir region coastal plain sabkhas are mainly siliciclastic in origin due to the dominance of quartz and feldspar over carbonates (Nabhan, 2004). Sabkha can be defined as saline flats in shallow, sometimes extensive, depressions, and their deposits are commonly saturated with brine and are salt encrusted. The presence of salt is the distinguishing feature of the sabkha (Powers, et al., 1966, p.127). Two types exist; namely, coastal sabkha that is a supratidal deposit produced by depositional offlap of marine sediments, with associated brine derived primarily from sea-water; and inland sabkha that lies away from the coast and represents regions of equilibrium between aeolian sedimentation and deflation that are controlled by the local water table 
(Johnson, et al., 1978). Asir region coastal plain, the sabkha surface, seems flat with no physical obstacles. It is mainly siliciclastic in origin, and the sediment type is silt sediments (Plate 7).

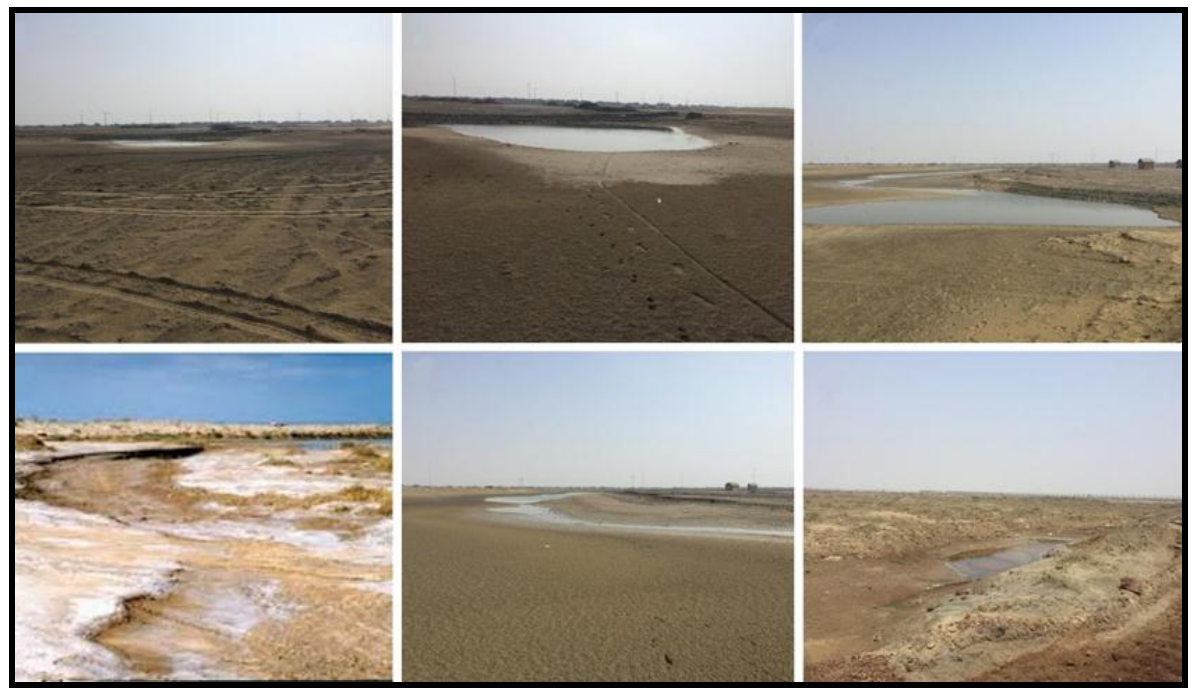

Plate 7. Photos showing salt marshes and sabkhas, field Study in the Area on 7/1/2020.

\subsection{Drainage Systems (Wadis):}

Asir region coastal plain is traversed by five wadis from south to north: Itwad, Al-Birk, Rim, Aramram and Nahab from south to north (Plate 8). They extend several kilometers inland ranging from 29 to $52 \mathrm{~km}$ in length. These wadis formed at lowered sea levels and are considered as the geomorphological features which resulted from the geologic events of the Late Quaternary. By and large, the coast dominantly shows terrigenous sediments of gravely sand to muddy sand. The wadis are ephemeral and active sediment supply channels, only during flash floods (Al-Sayari and Zotl, 1978). These seem to be localized and of variable intensity, which can transport even gravel-sized sediments that are noticed in the beach zone.

\subsection{Vegetation:}

Vegetated regions occur in several places, north of the coastal plain of Asir region. Wadi Nahab is covered by Doum palm (Hyphaene thebaica). Some vegetation is observed between Wadi Aramram and Wadi Rim (Plate 9). A range of plants is adapted to saltwater, and these form salt-marsh communities in the intertidal zone along sheltered mud coasts. Along the coastline, mangroves are an important element in coastal vegetation. Together with other halophytic plants, they may play a geo-morphic role by trapping sediment within their root systems, so aiding the depositional process (Summerfield, 1991). 


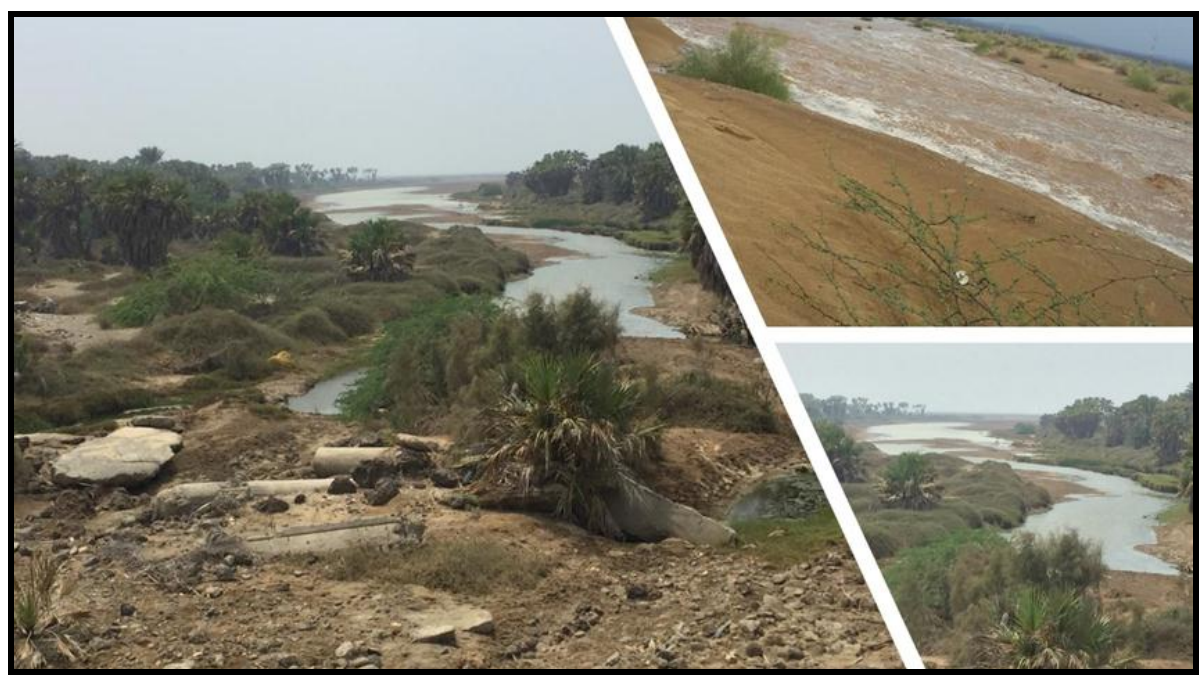

Plate 8. Photos showing drainage systems (Wadi Aramram and Wadi Rim), field Study in the Area on 5/1/2020.

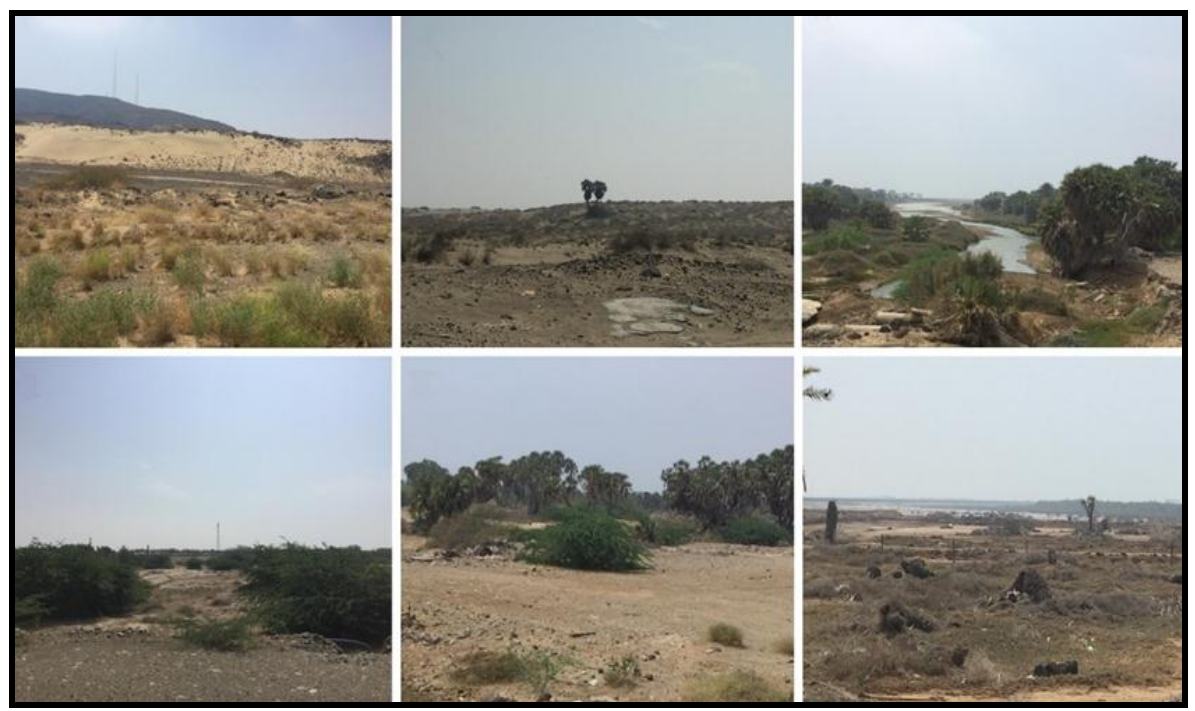

Plate 9. Photos showing vegetation between Wadi Aramram and Wadi Rim, field Study in the Area on 8/1/2020.

\subsection{Lagoons:}

The coastal plain of Asir region is considered as shallow depressions that retain water even at low tide. Some lagoons occupy mouths of ancient wadis, and others developed in tidal regions that gradually developed into tidal flat environments (Plate 10). A small part of the coastline is developed 
as a barrier coastline. Lagoons are considered as shallow depressions that remain water filled even at low tide.

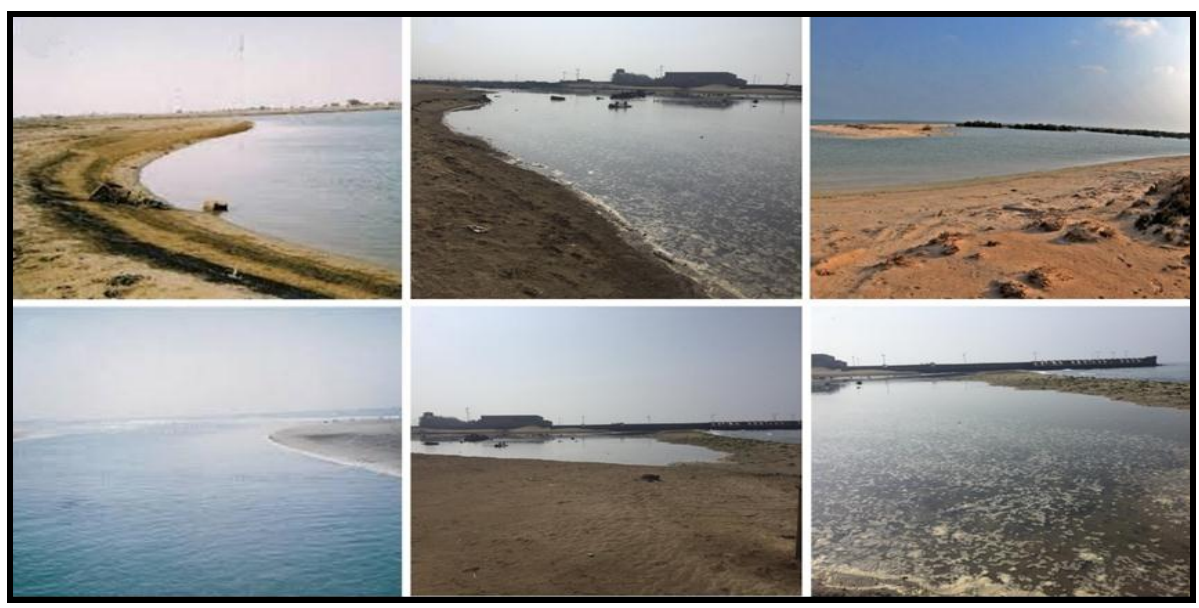

Plate 10. Photos showing some lagoons occupying mouths of ancient wadis and others developed in tidal regions field Study in the Area on 6/1/2020.

A small part of the coastline changed to a barrier coastline that opens into the Red Sea by inlet. However, the size and number of inlets of a lagoon depend upon the quantity of water which flows through it during a given time (Reineck \& Singh, 1975). The amount of water is controlled by tidal range and number of tides per day.

Some of the coastal lagoons of the coastal plain of Asir region are hyper-saline as no fresh water comes into the lagoons except from mouths of the wadis that are flooded during rainy storms by the fresh water drained into the lagoon, causing a decrease in salinity. Most of the lagoons with normal salinity show faunal similarity with those of the open sea (Abou Ouf, 1996). However, with a change in salinity, the fauna gets impoverished. Mangrove vegetation is present due to the tropical climate, along with algal mats. During desiccation, mud cracks are usually developed.

\subsection{Coral Reefs:}

A number of studies have examined the geo-morphology of coral reefs with attention being focused on Holocene reef growth and island development. Woodroffe, et al. (1999) considered the development of atoll reef-islands and Woodroffe, et al. (2000) described platform and fringing reef growth. Kennedy and Woodroffe (2002) provide a review of fringing reef growth and morphology. Besides, Woodroffe and Morrison (2001) report on the late Holocene accretionary history of reef islands in western Kiribati. Reef 
sediments and reef sedimentation in the islands are described by Kench (1997) and at the latitudinal limits of reef growth at island by Kennedy and Woodroffe (2000) and Kennedy (2003). Harriott and Banks (2002) presented a biophysical model for the latitudinal variation of reef growth. In addition, Rasser and Riegl (2002) investigated reef rubble production and binding in terms of process studies, but an understanding of the morpho-dynamics of reef platform and reef islands remains poor (Plate 11). The significance of this knowledge gap is highlighted by recent modelling of the morphological response of atoll islands to sea-level rise (Cowell and Kench, 2001; Kench and Cowell, 2001).

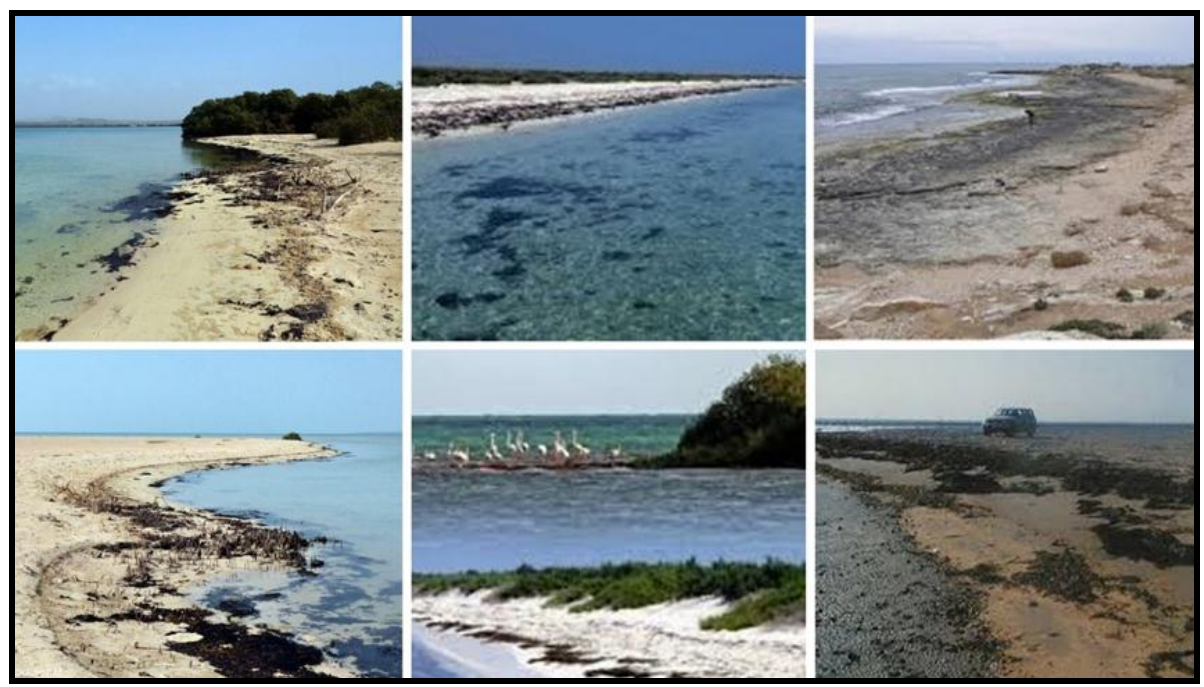

Plate 11. Photos showing coral reefs, field Study in the Area on 8/1/2020.

\subsection{Islands:}

Most of the islands of the Kingdom of Saudi Arabia are concentrated near the coasts due to the expansion of the continental shelf. Thanks to the nature of the Kingdom's formation, the coasts of the Kingdom and some of its islands are the elements of tourist attraction in terms of topographical and environmental diversity. It is represented by soft sandy beaches, mountainous heights and vegetation in addition to the various coral reefs that surround the islands. This qualifies them to be a popular destination for visitors to pursue hobbies: fishing, diving, rest and recreation in most seasons of the year. The coast of Asir region is characterized by the presence of 26 marine islands that are characterized by their diversity in their environments and natural characteristics. Among the most important of these islands in front of the coasts of Asir lie Jabal Kutumbul, Qatna, Hasr, Marca, and Jabal Zhahban (Plate 12). 


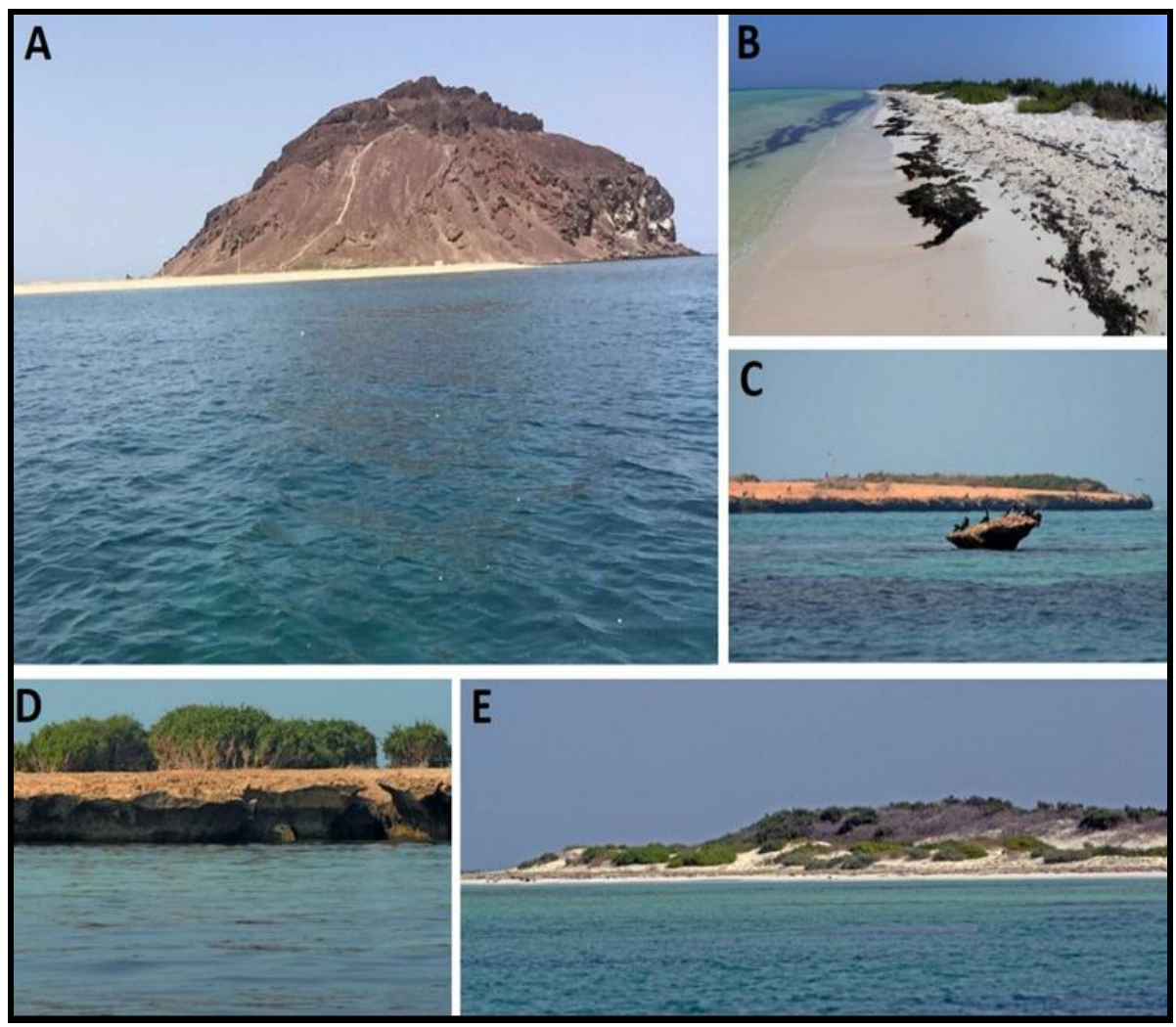

Plate 12. Islands of the coasts of Asir region, A Kutumbul Island, B Qatna Island, C Hasr Island, D Zhahban Island, E Marca Island, field Study in the Area on 9/1/2020.

\section{Sediment Characteristics of Coastal Landforms:}

Analyses of sediment samples from coastal landforms are important for any geo-morphologic work in the study area. Texture variation and transportation of the sediment is discussed as follows:

- The average size of the samples is between fine sand and very fine sand due to the effect of the wadis in bringing sediments because they are the mouths of the wadis area. From studying Table (2), to find analysis of samples ranging from medium to well-classified confirms the extent of the homogeneity of the sediment, and no differences were found in the values of the classification coefficient.

- The average torsion of sediment sizes ranges between negative and very negative, as well as symmetric and positive skewness, but it is mostly negative skewness that shows that the study area is exposed to a strong marine destruction, a high energy capable of corroding and transporting materials into the sea. 


\begin{tabular}{|c|c|c|c|c|c|c|c|c|}
\hline 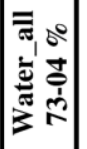 & $\hat{\tilde{n}}$ & ஜ̂ & $\underset{\infty}{\tilde{\sigma}}$ & $\stackrel{\infty}{\stackrel{\infty}{\sigma}}$ & $\underset{\infty}{\infty}$ & ণิ & 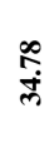 & ฮ \\
\hline 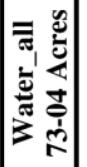 & $\underset{\mathscr{n}}{\stackrel{m}{f}}$ & $\underset{\Xi}{\Xi}$ & 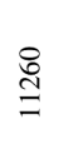 & $\begin{array}{l}n \\
\infty \\
\infty \\
\infty\end{array}$ & $\begin{array}{l}\text { fo } \\
\stackrel{0}{0}\end{array}$ & $\frac{\infty}{\infty}$ & సे & 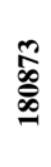 \\
\hline 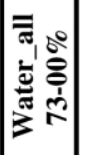 & $\begin{array}{l}\vec{b} \\
\infty \\
\infty\end{array}$ & $\stackrel{n}{\infty}$ & $\begin{array}{c}\tilde{\infty} \\
\text { r. }\end{array}$ & $\tilde{n}$ & 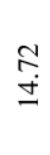 & $\begin{array}{l}\infty \\
0 \\
0\end{array}$ & लें & ฮ̊ \\
\hline 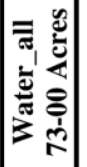 & 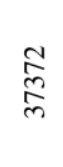 & 孛 & $\bar{\sigma}$ & స్ & స్ న్ & 苍 & $\stackrel{i n}{n}$ & $\begin{array}{l}\stackrel{0}{\circ} \\
\stackrel{0}{\infty}\end{array}$ \\
\hline 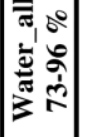 & $\underset{\text { ते }}{\text { ते }}$ & กู่ & గ্ণ & $\stackrel{\infty}{\stackrel{\infty}{r}}$ & $\begin{array}{l}\stackrel{0}{+} \\
\text { in }\end{array}$ & 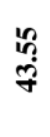 & ڤึ. & ఏ \\
\hline 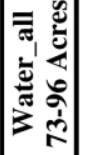 & 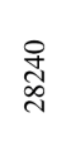 & $\frac{\hat{m}}{\infty}$ & $\begin{array}{l}\infty \\
0 \\
0 \\
0\end{array}$ & స్ & 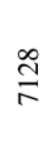 & $\begin{array}{l}\infty \\
\infty \\
: 0 \\
\text { : } \\
\text { in }\end{array}$ & $\stackrel{\vec{m}}{\stackrel{n}{n}}$ & $\begin{array}{l}\stackrel{2}{\circ} \\
\stackrel{0}{\circ}\end{array}$ \\
\hline 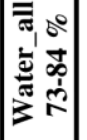 & $\begin{array}{l}\stackrel{+}{+} \\
\stackrel{2}{2}\end{array}$ & $\underset{m}{\stackrel{J}{*}}$ & ?̊ & $\stackrel{\infty}{=}$ & ָூ & $\underset{\substack{+\infty \\
\infty}}{\infty}$ & กุ้ & ฮิ \\
\hline 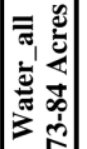 & $\begin{array}{l}\text { fે } \\
\text { तn }\end{array}$ & 守 & $\stackrel{n}{n}$ & $\stackrel{\overline{\mathcal{F}}}{\stackrel{\mathrm{g}}{2}}$ & $\widehat{\widetilde{O}}$ & กิ & ర్లో & 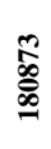 \\
\hline 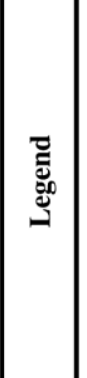 & 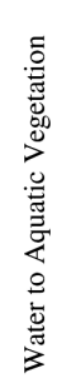 & 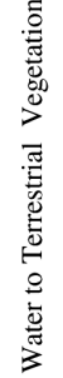 & 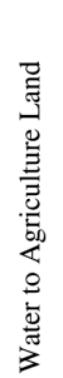 & 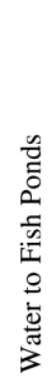 & 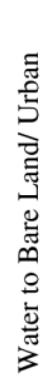 & 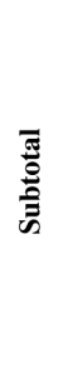 & 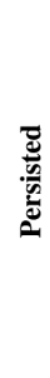 & है \\
\hline
\end{tabular}


Special studies of coasts indicate that the rate of corrosion is higher than that of precipitation. Marine processes select less rough sizes. Therefore, larger sediments remain on the foreshore. It is found that the beaches exposed to corrosion are characterized with bigger and rougher components than those on the shores exposed to deposition, and the difference between them is very limited. This is due to two reasons:

- First, the study area is unstable in corrosion and sedimentation processes, whether on the level of the months of the year or for one month because it is the only place exposed to the corrosion in that period and then exposed to aggradation at another time.

- Second, the presence of heavy metals, as they are of great importance, reflects the conditions of each of river and marine corrosion and aggradation, especially in a highly sensitive area such as the study area. The beaches of corrosion have a high percentage of heavy metals that had to be eroded and to transport sediments. They have a low specific weight, although relatively rough.

Marine processes leave heavy metals on the beach although they are classified of fine and very fine sand. Conversely, with high density, maritime operations are unable to carry them and thus they remain on the foreshore.

It can be seen that heavy metals, known as the black sand, are clearly scattered on the beach, and they take different forms such as fans and aids, semi-parallels and others, Plate (4) photos showing black sand beach, especially in beach destinations that are exposed to the carving and less concentrated than black sand, as they far away from the mouths of the valleys area. Besides, the source of these heavy metals is the wadis where they come from the upper sources which are the Asir Heights. This explains the accuracy of their sizes.

\subsection{The Near-shore Sediments:}

The near-shore sediments in the coastal plain of Asir region can texturally be classified as dominantly muddy sand, along with gravelly muddy sand at few places. Carbonate content varies between $2 \%$ and $93 \%$ with an average of $21 \%$. Carbonate concentration appears to be very low near the shore, especially in front of wadi mouths due to dilution by the terrigenous material. In the extreme north, gravel content shows an increase.

The near-shore sediment sources appear to be a combination of material eroded from the basaltic cliffs and alluvial terraces by wave action and relict sediment, originally from the ancient wadis in the area, and transported onshore by northwesterly waves or wind during sea level low stands. Littoral source for this sediment is supported by its calcareous composition character 
and similarity to coral reef sediments. Under high energy or storm conditions, part of the beach sediments is typically eroded and carried offshore.

\subsection{Beach Sediments:}

Beach or shore landforms include well-developed foreshore and backshore. Beach bar or ridge is common and consists of coarse-grained gravelly sands. This bar occurs between mouths of wadi Aramram and wadi Nahab as remnant or a more recent shore feature that is formed by modern filling.

The coastal plain of Asir region is mainly composed of sand fraction toward the gravel coarse fraction in the beach zone. Besides, the beach zone is composed mainly of medium to fine-grained sand especially in the intertidal zone and sometimes gravel, with moderately sorted to moderately well-sorted sediments in the backshore zone.

\subsection{Sand Dune Sediments:}

Sand dunes are identified as high coastal Seif and Barchan dunes that move landward. Extensive low dunes field and scanty vegetation parallel to the shoreline as a foredune ridge are the characteristic features of the beach zone. The Aeolian material transported as a drag from local sources and as a suspended load from regional sources is another important source. Graphic grain-size parameters, determined by Nabhan (2004), prove that Mz varies between medium grained and fine-grained. However, sorting values fit into moderately well-sorted to well-sorted. It is concluded that sorting is related to dune morphology where the dune ridge has better sorted coarse-grained sand than the inland Barchan and Seif dunes, indicating sediment derivation from the beach zone.

\subsection{Wadi Sediments:}

The coastal plain of Asir region is cut across by five wadis from south to north: Itwad, Al-Birk, Rim, Aramram and Nahab. These wadis affect the deposition in the shelf marine environment since they provide the area with huge amounts of detritus material derived from the adjacent high fringing Tertiary mountains. These wadis get occasionally flash floods at a time when the rainfall is extensive in the region. The texture analyses of the selected samples from these wadis show that they are mainly composed of muddy sand, sand and sandy mud. Gravels constitute a low amount; however, one can see many boulders, cobbles and pebbles everywhere at the mouths and in the channels, especially at wadi Nahab probably due to proximity of rocky hills on the pathway of the wadi. 


\subsection{Lagoon Sediments:}

The coastal plain of Asir region includes two lagoons: Tanah and Masud. They were formed due to the presence of a gap in the weak sections of the shore through tidal inlet. Their sediment analyses exhibit various textural ranges: muddy sand, muddy gravelly sand, gravelly sand and sand. Tanah has relatively finer sediments (sandy mud and sand).

\section{Conclusions}

The interpretations of GIS and RS of the coastal plain of Asir region together with the field study and the collected sample help understand how coastal geo-morphology, lithology and tectonics influence distribution and transport of near-shore littoral sediments. The coastal plain of Asir region is largely bounded from the north by resistant headlands and long stretches of wide sand beaches backed by dune fields toward the south with marine limestone platform terraces seaward. Numerous wadis drain this region and contribute to the vast majority of the total input of sediments to the coastal zone. Most of the paleo-drainage in the coastal plain of Asir region has stopped carrying sediments, except in rare flash floods. Remnants of coarse gravel(s), along the shoreline with thin sheets of coarse-grained sediments, occur in the middle part of the coast corresponding to biogenic shoreline sediments in the extreme south. They are made largely of skeletal grains. The coastal plain of Asir region can be divided into the following units: foreshore, backshore, swamps, tidal inlets, tidal flats and sand dunes. Sea cliffs, coral reef platforms and wadis are the major factors controlling the development and changes in the region. Sometimes, the beach appears as a ridge. This makes the shoreline marked as a sand bar that is formed by the flooding of wadis through rainy seasons. Patches of gravels are present near the mouths of Itwad, Al Birk, Rim, Aramram and Nahab. Along the lowlying Asir coast, sediment cover is generally thick and the distribution of littoral sediments on the shoreface provides important information regarding not only the sources of the sediments but also the modes and pathways of transport. 


\section{References}

1. Abou Ouf MA, El Shater A (1992): Sedimentology and mineralogy of Jizan shelf sediments, Red Sea, Saudi Arabia. JKAU: Mar Sci., 3: 39-54.

2. Abou Ouf, M., Durgaprasada Rao, N.V.N. and Taj, R.J. (1988): "Benthic foraminifera from littoral sediments of Al Lith - Al Qunfidah coast, south eastern Red Sea", Indian Journal of Marine Sciences, 17(3): 217-221.

3. Alharbi OA, Philips MR, Williams AT, Bantan RA (2011): Landsat ETM applications: identifying geological and coastal landforms, SE Red Sea Coast, Saudi Arabia. In: Özhan E (Editor), Proceedings of the Tenth International Conference on the Mediterranean Coastal Environment, MEDCOAST 11 (Rhodes, Greece), pp. 985-996.

4. Alharbi OA, Phillips MR, Williams AT, Gheith AM, Bantan RA, Rasul NM (2012): Desalination impacts on the coastal environment: ash Shuqayq, Saudi Arabia. Sci Total Environ 421: 163-172.

5. Al-Sayari, S.S. and Zotl, J.G. (1978): Quaternary Period in Saudi Arabia, Springer-Verlag, Wien, New York, p. 335.

6. Al-Washmi HA, Gheith AM, Nabhan AI (2005): Geomorphological features, sediment distribution and transport along Ash Shuqayq-Al Haridhah coastal area, Southern Red Sea. Journal of the Faculty of Marine Science, King Abdulaziz University 16: 57-80.

7. Al-Welaie A (1996): Geology and Geomorphology of the Kingdom of Saudi Arabia (in Arabic). Riyadh, King Fahad National Library, p. 526.

8. Basyoni, M.H. (1997): Sedimentological and Hydrochemical Characteristics of Al- Lith Sabkha, Saudi Arabia, J KAU, Earth Sci., 9: 75-86.

9. Bird, E.C.F. (1984): "Coasts. An Introduction to Coastal Geomorphology", $3^{\text {rd }}$ edition. Basil Blackwell Publisher Limited.

10. Coleman, R.G. (1984): The Tihamat Asir igneous complex: A passive margin ophiolite, Proceedings of International Geological Congress, 27th, Moscow: Utretch, The Netherlands, 9: 221-239.

11. Folk, R.L. (1962). Petrology of Sedimentary Rocks, Hemphill, Auston, Texas, $182 \mathrm{p}$.

12. Folk, R.L. and Ward, W.C. (1957): Brazos Rivers Bars, a Study in the Significance of Grain Size Parameters, J. Sed. Petrol., 27: 3-27.

13. Gheith, A.M. (1999): Mineralogy and Diagenesis of Coastal Sabkha Sediments of the Hypersaline Lagoons on the Eastern Coast of the Red Sea, Saudi Arabia, Arabian Gulf, J. Scientific Res., 17(2): 199-219.

14. Gheith, A.M. (1999): Mineralogy and Diagenesis of Coastal Sabkha Sediments of the Hypersaline Lagoons on the Eastern Coast of the Red Sea, Saudi Arabia, Arabian Gulf, J. Scientific Res., 17(2): 199-219.

15. Gheith, A.M. (2000a): "Sedimentary reflection of the coastal processes on the shore zone Sediments along the eastern Red Sea coast, Saudi Arabia", Z. Geomorph., 44(4): 449-468

16. Gheith, A.M. (2000b): "Use of surface features of quartz grains as indicators of various modern sedimentary environments along the eastern coastal plain of the Red Sea, Saudi Arabia", Arab Gulf Journal of Scientific Research, 18(3): 165-172. 
17. Gheith, A.M. and Abou Ouf, M. (1996): Geomorphological Features and Sedimentological Aspects of Some Coastal and Inland Sand Dunes, Jeddah Region, Saudi Arabia, Arab Gulf, J. Scient. Res., 14(3): 569-593.

18. Jado, A.R. and Zotl, J.G. (1984): Quaternary Period in Saudi Arabia, Vol. 2. Springer-Verlag, Wien, New York, p. 360.

19. Johnson, D.H., Kamal, M.R., Pierson, G.O., and Ramsay, J.B. (1978): "Sabkhas of eastern Saudi Arabia", In: Al-Sayari, S.S. and Zotl, J.G. (Eds.), Quaternary Period in Saudi Arabia, Spriger-Verlag, New York, pp. 84-93.

20. King, C.A.M. (1972): Beaches and Coasts. London.

21. Nbhan, A.E. (2004): "Geomorphological, sedimentological and mineralogical studies on the coastal zone of Ash Shuqayq, Southern Red Sea, Kingdom of Saudi Arabia", M. Sc. Fac. Marine Sci., King Abdulaziz Univ., Jeddah, Saudi Arabia.

22. Powers, R.W., Ramirez, L.F., Redmond, C.D., and Elberg, E.L., JR, (1966): "Geology of the Arabian Peninsula, sedimentary geology of Saudi Arabia", U.S. Geol. Survey Prof.

23. Reineck, H.E. and Sing I.B. (1975): Depositional Sedimentary Environments with Reference to Terrigenous Clastics, Springer Verlag, Berlin, New York, p. 439.

24. Schmidt, D.L., Hadley, D.G. and Brown, G.F. (1982): Middle Tertiary Continental Drift and Evolution of the Red Sea in Southwestern Saudi Arabia, Saudi Arabian Deputy, Ministry of Mineral Resources (DGMR), Open File Report USGS-OF-03-6-56P.

25. Summerfield, M. A. (1991): "Global Geomorphology, An introduction to the study of landforms", Michael A Summerfield, pp. 325-337.

26. Tag, R.J. (1986): Sedimentology and Mineralogy of Red Sea Coast Recent Sediment between Wadi Al-Fagh and Wadi Al Qunfudah, Saudi Arabia, M.Sc. Thesis, Fac. Earth Sci., King Abdulaziz Univ., Jeddah, Saudi Arabia. 


\title{
جيومورفولوجية السهل الساحلي لمنطقة عسير ، باستخدام تقتيات الاستثعار عن بعد ونظم المطلومات الجغرافية، المملكة العربية السعودية لمبلية
}

\author{
د. منا محمد عصام حسن العسال \\ أستاذ مساعد الجغرافيا الطبيعية (جيومورفولوجيا - جيوأركولوجيا) \\ قسم الجغرافيا، كلية العلوم الانسانية - جامعة الملك خالد، المملكة العربية السعودية
}

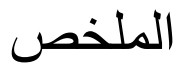

يمند السهل الساحلي بمنطقة عسير في جنوب غرب المملكة العربية السعودية. تم تحديد الملامح

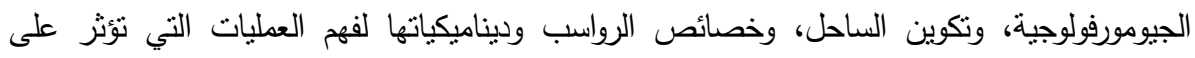

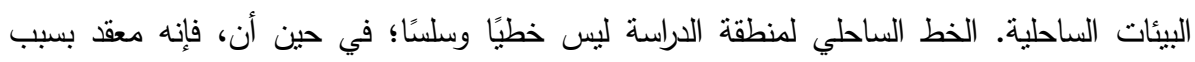

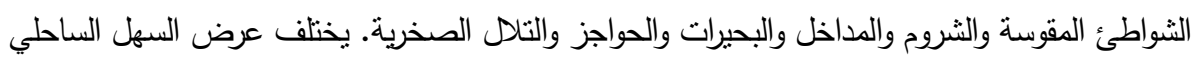
بثكل كيير. وهي واسعة وخالية من الملامح باتجاه جنوب منطقة الدراسة بينما نكون ضيقة وتحدها

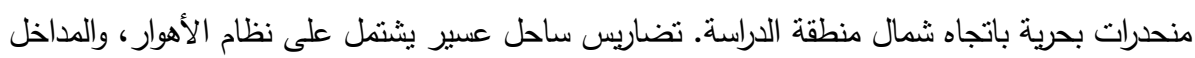
والمستقعات، والكثبان، وعمليات الثاطئ، والحواجز الثاطئية، وأنظمة الأودية والسبخات. تتخير الظروف

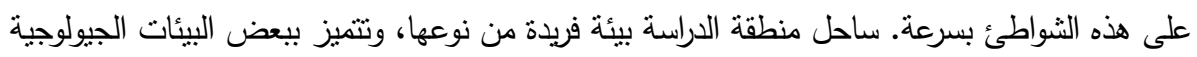
الرئيسية (متل الثعاب الساحلية، والهنجروف، والمستتقعات، والسبخات، والمراوح الرسوبية، والدنحدرات

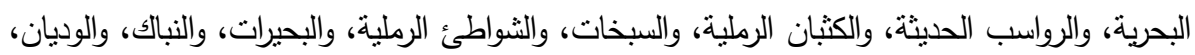
والثعب المرجانية والمواد العضوية والغطاء النباني). الهدف من هذه الورقة هو متابعة وتقييم البيئة وخصائص التضاريس. تتم الإجراءات السابقة من خال قياس التتوع البيولوجي، والتضاريسى والعمليات الجيومورفولوجية لتئية على الساحل. تستخدم الدراسة عدة طرق مثل الدراسة الميدانية، وجمع العينات من مختلف البيئات الجيومورفولوجية للمنطقة

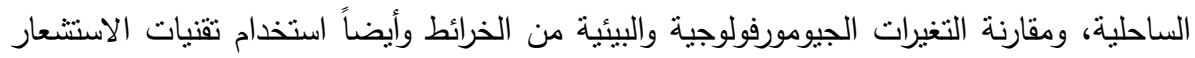
عن بعد ونظم المعلومات الجغرافية.

الكلمات المفتاحية: منطقة عسير، السهل الساحلي، الملامح الجيومورفولوجية، نظم المطلومات الجغرافية،

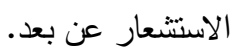

